\title{
Cyber Law Awareness among Youth of Malappuram District
}

\author{
Sukanya K P ${ }^{1}$, Raju C V. ${ }^{2}$ \\ 1 (Sub-Editor, Online Editorial, IE Malayalam, Indian Express, Kerala, India) \\ 2 (Guest Lecturer, Department of Journalism \& Mass Communication, University of Calicut, Kerala, India)
}

\begin{abstract}
World becomes more digitally sophisticated with the present technological environment. Being a part of e-world, we depend upon internet for various purposes. Earlier, internet was used for research and communication purposes alone. Today, it got extension into the fields like e-business, e-commerce and egovernance. The increased reliance on cyber space has paved way for a rapid growth in cyber-crimes. As the cyber-crime rate is on the rise, the need for cyber laws and its applications gather great momentum. Considering the case of India, Information Technology Act introduced in 2000 in order to deal with issues related to cyber space. This paper tries to find out awareness of Information Technology Act, 2000 among the youth of Malappuram district in Kerala. The paper is entitled as "Cyber Law Awareness among Youth of Malappuram District". Researchers also investigate youth's awareness on various sections in IT act, familiarity with cybercrimes, cyber- crimes offenders and victimized youth in Malappuram and security measures that they take in cyber space. Questionnaire survey was devised among the respondents who were selected using stratified random sampling. The study found that youth of Malappuram have a basic level of understanding on Information Technology Act, 2000 in India.
\end{abstract}

Keywords: Cyber space, Cyber-crime, Cyber attacks, Cyber law, Information Technology Act, 2000, Awareness, Youth

\section{INTRODUCTION}

Today we are living in an e-world. We connect to the whole world through internet. And we are growing along with the internet. Simply saying we are living in an online world. Being online means connected to the internet and keeping oneself up-to-date. Nowadays almost all communication takes place through the internet. Living in present without referring to the past is not possible. Get to know about the past is important for futuristic knowledge. The Internet has sixty years history to share. Before that, we have to answer the basic question what is internet? As the term suggests, the internet is the network of networks (Castells, 2002).

Before moving to analyze what cyber-crime is, we have to take a look into the word 'cyber' and its varying dimensions. The word cyber stands for computer or computer network. Simply anything related to the computer is categorised under the word cyber. The term "cyber" is derived from the term cybernetic which has got its origin from the Greek word 'kybernetes'. It possibly based on 1830s French cybernétique "the art of governing." The term was introduced by U.S mathematician Norbert Wiener in 1948 in his book "Cybernetics" to elaborate on the existing theory of the transmission of messages by incorporating his idea that people send messages within a system in an effort to control their surrounding environment.

Thomas and Loader define cybercrime as any computer-mediated activities which are either illegal or considered illicit by certain parties and which can be conducted through global electronic networks. Based on this definition we can classify cyber-crimes into different categories. They are computer-assisted crimes such as fraud, theft, money laundering, sexual harassment, hate speech and pornography. Another classification is computer focused crimes. These types of crimes came into existing after the introduction of the internet. They are hacking, viral attacks, website defacement etc. (cyber-crime and society, 2006)

With the increasing cyber-crimes all around the world, a large majority suffering financial and mental problems from that everyone required a legal system to overcome these crises. All nations felt the need of a legal system which deals cyber-crimes in our society. All nations have their own legal framework to deal mischievous activities happening there. First officials tried to adapt existing laws to cyberspace. But that was not much effective. There were lots of loopholes and difficulties in applying the general legal system to a virtual world like the internet. So the offenders can easily slip from cases registered on them. Many people who committed severe crimes easily broken knots of law. So this legal execution never created an impact that officials expected. So they started to think about a new legal system that can be applied to both computer and internet related crimes. Cyber law deals with internet, cyberspace and their respective legal problems. Or in other words, it includes matters like freedom of expression, access to and usage of the Internet, and online privacy. 
A cyber crime is occurring in every fraction of second. The present study aims to find out publics' legal awareness towards these crimes. It is necessary to check people's familiarity with cyber law in India. The Information Technology Act is reaching its 17th year of implementation. So it is important to find out whether citizens of India have any kind of familiarity with this act. Success of an act depends upon its familiarity among common man in the nation. Cyber space is one of the place people easily get trapped in. So, being the regular visitors of the online world, it is necessary to check users familiarity with legal measures applied in this world. Or in other words it is important to check Indians familiarity with Information Technology Act applied in cyberspace in 2000. The present study tries to find out the awareness of cyber law among the youth of Malappuram district in Kerala.

\section{REVIEW OF LITERATURE}

Tan KarPeng from American Casualty Express Insurande Asia Pacific, Singaporeand Chennupati K Ramaiah from MuffakhamJah College of Engineering \& Technology (2007) studied about cyber law awareness of Singaporeans. The paper is entitled as 'Awareness of Cyber Laws in Young Singaporeans'. Questionnaire tool was used to find out Singaporeans general awareness on cyber laws and other computer security measures. The survey conducted among a cross section of the young computer users in the country. Researchers findings were most of the users were not able to keep updated with latest information regarding computer security and this observation is consistent across different fields in Singapore. All the participants in survey agreed to need for ethics in internet usage and problems related to internet are obvious and cannot be avoided.

Ludwig Slusky and ParvizPartow-Navid's (2011)in their research paper entitled as 'Students Information Security Practices and Awareness' noticed that living in a cyber threats increasing cyber world some sort of information security is needed. They conducted an information security awareness survey among students of College of Business and Economics at California State University, LosAngeles. Their major finding was problem with security awareness is not due to lack of security knowledge, but it is the way students apply knowledge in real world situations. Information security awareness is lower than that of its understanding.

Ms.Aparna and Dr.Meenal Chauhan (2012) from GJIMT, Ph-II,Mohali, India presented a paper entitled as 'Preventing Cyber Crime: A Study regarding awareness of Cyber Crime in Tricity'. This paper provides an overview of cyber crime and examines awareness of issues of cyber crime among IT professionals. Researchers aim was to point out seriousness of this security issue and need of limits its impact worldwide. Objectives of the study were to find out whether or not people use internet to report cyber crimes. Other was to check awareness level of cyber crimes among people. Survey used to collect data from respondents.

Pardeep Mittal and Amandeep Singh (2013) in their work titled as 'A study of Cyber Crimes and Cyber Laws in India' concentrates on the points how to make Indians literates in cyber law. This paper focuses on various aspects of cyber crimes and cyber law in India. Researchers suggest that create awareness in common men to register their complaints related to cyber crime. And includes methods for registering have been included for effective implementation of law.

Saroj Mehta and Vikram Singh (2013) Department of Computer science Chaudhary Devi Lal University, Sirsa in their study entitled 'A Study of Awareness about Cyber Laws in Indian Society' analyses netizens (users of internet) awareness about Indian cyber law. The study conducted among students, teachers and employees. Questionnaire survey and random probability sampling were used to collect data. The findings were there is a significant difference in male and female netizens awareness about cyber laws in India. And male community is more aware about these laws than that of female community.

\section{OBJECTIVES OF THE STUDY}

Generally the study attempts to find out the cyber law awareness of youth of Malappuram district, Kerala. To fulfill this goal, following objectives were set:

1. To find out the significance of relationship between familiarity of Information Technology Act and awareness among the respondents.

2. To find out the familiarity of youth with the various cyber-crimes in cyber space

3. To understand the familiarity of youth with computer security measures

\section{METHODOLOGY}

To meet the objectives of the study, researchers followed survey research among samples. Samples were youth in Malappuram district. And they were characterized with an age group of 18 to 35. Study samples were chosen from a population who uses computer and internet facilities in daily life. And questionnaire tool was used to collect data from samples.

\section{SAMPLING PROCEDURE}

Stratified random sampling was used for this study. Here researcher stratified total population into sub groups on the basis of taluks. There are 7 taluks in Malappuram district. They are Perinthalmanna, Nilambur, Ernad, Kondotty, Ponnani, Tirur and Thiroorangadi. Out of which three taluks namely Thiroorangadi, Ponnani 
and Tirur were selected for sampling. Local bodies like one grama Panchayat and municipality were selected from each taluk for study. Tirur municipality and Tanalur panchayath were taken from Tirur taluk. Ponnani municipality and Kalady panchayath were taken from municipality of Ponnani. And Parappanaghadi municipality and Vallikunnu panchayath were taken from Thiroorangadi taluk respectively. And 50 questionnaires were distributed in each three taluks in Malappuram. Questionnaire tool was used to gather data from sample respondents. Questionnaires were distributed randomly among youth in selected muncipalities of Malappuram district.

\section{RESULTS}

The present study titled 'Cyber Law Awareness among Youth of Malappuram District' used questionnaire survey method as the major tool for collecting required data. Stratified random sampling was applied to choose the respondents from population of Malappuram district. As mentioned earlier the study was conducted among youth belonging to different age groups with the youngest sample being 18 years old and the eldest being 35 years old. The total sample size for the study was set at 150 . Out of the 150 questionnaires 145 were filled and returned. Out of these 135 appropriate questionnaires were taken up for the analysis as the rest were incomplete

\section{VI.1 Sample profile}

The respondents were requested to mark their gender, area of living, age group and educational qualification.

Table 1. Sample profile

\begin{tabular}{|c|c|c|}
\hline Characteristics & Parameters & Frequency (\%) \\
\hline \multirow{3}{*}{ Gender } & Male & $74(54.8 \%)$ \\
\cline { 2 - 3 } & Female & $61(45.2 \%)$ \\
\hline \multirow{2}{*}{ Area of living } & Rural & $76(56.3 \%)$ \\
\cline { 2 - 3 } & Urban & $59(43.7 \%)$ \\
\hline \multirow{3}{*}{ Ege group } & $18-25$ & $55(40.7 \%)$ \\
\cline { 2 - 3 } & $26-30$ & $32(23.7 \%)$ \\
\cline { 2 - 3 } & $31-35$ & $48(35.6 \%)$ \\
\hline \multirow{2}{*}{ Education } & Up to Plus two & $34(25.2 \%)$ \\
\cline { 2 - 3 } & Under Graduation & $54(40.0 \%)$ \\
\cline { 2 - 3 } & P.G and above & $47(34.8 \%)$ \\
\hline
\end{tabular}

A simple majority (56.3\%) of the sample population belongs to rural areas of Malappuram. And the rest (43.7\%) is from urban areas of Malappuram. A simple majority (54.8\%) of the sample is male and the rest of them $(45.2 \%)$ are females. The age group of samples was limited to 18 to 35 . The data show that large minority (40.7\%) of sample belongs to $18-25$ age groups. The second highest minority (35.6\%) is from 31 to 35 age groups. The least minority (23.7\%) is grouped under 26 to 30 age group. The educational status of the samples is also varying. A large minority $(40.0 \%)$ of the samples are under graduated. The second highest minority (34.8\%) have an educational qualification of post graduation and above. A small minority (25.2\%) has an up to plus two level of education.

\section{VI.2 IT Act Awareness}

It deals with respondent's familiarity with Information Technology act, 2000. It contains information like familiarity with act and source of information about act.

Table 2. Familiarity with IT act, 2000

\begin{tabular}{|l|l|ll|}
\hline Familiarity level & Frequency & Percent \\
\hline Not familiar & 44 & 32.6 & \\
\hline Familiar & 91 & 67.4 & \\
\hline Total & 135 & \multicolumn{2}{l|}{100.0} \\
\hline
\end{tabular}

A large majority of sample population are familiar with Act applied in cyber world. In this section respondents were asked to recognize their familiarity with IT Act, 2000. Response from samples shows that a large minority (32.6\%) totally unfamiliar with IT Act, 2000. But a large majority (67.4\%) is familiar with this act in 2000. 
Table 3: Source of awareness about IT Act, 2000

\begin{tabular}{|l|l|l|}
\hline Source of awareness & Frequency & Percent \\
\hline Self-study & 11 & 8.1 \\
\hline Media & 32 & 23.7 \\
\hline Academic learning & 38 & 28.1 \\
\hline Internet & 10 & 7.4 \\
\hline Not Familiar & 44 & 32.6 \\
\hline Total & 135 & 100.0 \\
\hline
\end{tabular}

A large minority $(28.1 \%)$ came to know about IT Act from academics. Media became a source for a large minority $(23.7 \%)$ of sample. A least minority $(8.1 \%)$ studied about this their selves. A few of them $(7.4 \%)$ studied about this from internet.

Table 4: Act awareness by Education of respondents

\begin{tabular}{|c|c|c|c|}
\hline \multirow{2}{*}{ Education } & \multicolumn{2}{|c|}{ Familiarity } & \multirow{2}{*}{ Total } \\
\cline { 2 - 3 } & No & Yes & \\
\hline Up to Plus Two & $14(31.8)$ & $20(22)$ & $34(25.1)$ \\
\hline Under Graduation & $18(41)$ & $36(39.5)$ & $54(40)$ \\
\hline Post Graduation \& above & $12(27.2)$ & $35(38.5)$ & $47(34.9)$ \\
\hline Total & $44(32.6 \%)$ & $91(67.4 \%)$ & $135(100.00)$ \\
\hline Pearson chi-square $=2.220, d f=2, p$ value $=\mathbf{3 3 0}$ \\
\hline
\end{tabular}

(Note: Figures in parentheses denote percentage)

Education doesn't have a role in familiarity with IT Act, 2000. While analyzing the relationship between them, vast minority $(41 \%)$ undergraduates are unfamiliar with this act. A large minority $(27.2 \%)$ of unfamiliar samples has PG and above educational qualification. And from the unfamiliar group a large minority $(31.8 \%)$ has a plus two level of education. Samples who agreed they are familiar with act, a large minority $(39.5 \%)$ were undergraduates. The most educated group consists $38.5 \%$ of familiar samples. And the least minority (22\%) among familiar group has an up to plus two level of education. However, statistically the relationship between act familiarity and education is insignificant ( $\mathrm{p}$ value $=.330$ ).

Table 5: Act awareness by area of living

\begin{tabular}{|c|c|c|c|}
\hline \multirow{2}{*}{ Area } & \multicolumn{2}{|c|}{ Familiarity } & \multirow{2}{*}{ Total } \\
\hline & No & Yes & \\
\hline Rural & $29(66$ & $47(51.7)$ & $76(56.3)$ \\
\hline Urban & $15(34$ & $44(48.3)$ & $59(43.7)$ \\
\hline Total & $6 \%) \quad 44(32$. & $91(67.4$ & $135(100.00)$ \\
\hline
\end{tabular}

(Note: Figures in parentheses denote percentage)

Analyzing the relationship between act familiarity and area of living, the geographical difference doesn't play a crucial role in awareness. Taking samples who unfamiliar with act a large majority (66\%) is from rural area. The rest of them $(34 \%)$ were from urban areas of Malappuram. This means respondents from rural area are totally unfamiliar with IT Act, 2000. Considering act familiar respondents a simple majority (51.7\%) is from rural areas. And a vast minority (48.3\%) lives in urban areas of Malappuram. The table shows that place of living is not important in awareness of act. Statistically the relationship is insignificant ( $\mathrm{p}$ value $=.117$ ). 
Table 6: Act awareness by gender

\begin{tabular}{|c|c|c|c|}
\hline \multirow{2}{*}{ Gender } & \multicolumn{2}{|c|}{ Familiarity } & \multirow{2}{*}{ Total } \\
\hline & No & Yes & \\
\hline Male & 7) $21(47$. & 2) $\quad 53(58$. & $74(54.8)$ \\
\hline Female & 3) $23(52$. & 8) $38(41$. & $61(45.2)$ \\
\hline Total & $6 \%) \quad 44(32$. & $4 \%) \quad 91(67$. & $135(100.00)$ \\
\hline
\end{tabular}

(Note: Figures in parentheses denote percentage)

Analyzing the role of gender in act familiarity, a simple majority $(52.3 \%)$ of unfamiliar samples were females. Vast minority (47.7\%) male respondents are unfamiliar with IT Act, 2000. And a simple majority $(58.2 \%)$ of male respondents is familiar with this act. The rest of familiar group is female respondents $(41.8 \%)$ of survey. However, statistically value denies the relationship between act familiarity and gender. That is statistically the relationship is insignificant ( $p$ value $=.250)$.

Table 7: Act awareness by age group

\begin{tabular}{|c|c|c|c|}
\hline \multirow{2}{*}{ Age Group } & \multicolumn{2}{|c|}{ Familiarity } & \multirow{2}{*}{ Total } \\
\hline & No & Yes & \\
\hline $18-25$ & .5) $20(45$ & 4) $\quad 35(38$ & $55(40.7)$ \\
\hline $26-30$ & .4) $16(36$ & $16(17$. & $32(23.7)$ \\
\hline $31-35$ & 1) $8(18$. & $40(44)$ & $48(35.6)$ \\
\hline Total & $\begin{array}{ll}.6 \%) & 44(32\end{array}$ & $4 \%) \quad 91(67$. & $135(100.00)$ \\
\hline
\end{tabular}

(Note: Figures in parentheses denote percentage)

Observing the relationship between act familiarity and age, they are closely associated each other. Among samples who unfamiliar with IT Act, 2000, a vast minority (45.5\%) belongs to 18-25 age group. The rest of unfamiliar constitutes a minority of 36.4\% from 26-30 and 18.1\% from 31-35 age group respectively. While considering the case of act familiar ones the most seniors consists $44 \%$ of sample population. The juniors of sampled youth aged between 18 to 25 consists $38.4 \%$ of familiar group. And the age group of 26 to 30 is the simple minority $(17.6 \%)$ in familiar group. However, statistical value accepts the relationship act familiarity and age. That is statistically the relationship is significant ( $p$ value=.006).

\section{VI.3 Familiarity with cyber crimes}

Samples were asked to recognize cyber-crimes familiar to them. Crimes were divided in to three categories: crime against individual, Crime against property and Crime against society.

Table 8: Familiarity with crimes against individual

\begin{tabular}{|l|l|l|}
\hline Cyber-crimes & Familiar & Not familiar \\
\hline Spamming & $72(53.3 \%)$ & $63(46.7 \%)$ \\
\hline Phishing & $58(43 \%)$ & $77(57 \%)$ \\
\hline Cyber stalking & $32(23.7 \%)$ & $103(76.3 \%)$ \\
\hline Social engineering & $39(28.9 \%)$ & $96(71.1 \%)$ \\
\hline Identity theft & $68(50.4 \%)$ & $67(49.6 \%)$ \\
\hline Cyber Pornography & $62(45.9 \% 0$ & $73(54.1 \%)$ \\
\hline
\end{tabular}

(Note: Figures in parentheses denote percentage)

While moving through familiarity table of cyber-crime terms, majority of sample population is unfamiliar with these terms. Cyber stalking and social engineering are quiet unfamiliar term for the respondents. 
A simple majority (53.3\%) are familiar with the crime spamming. At the same time a vast minority $(46.7 \%)$ don't have any familiarity with spamming. Considering the term phishing, a simple majority (57\%) sample is totally unfamiliar with it. But a vast minority (43\%) knows the term. Being the most often crime in India, a large majority $(76.3 \%)$ are strange to cyber stalking. A large minority $(23.7 \%)$ is familiar with this crime. A large majority of sample $(71.1 \%)$ are unfamiliar to social engineering. Its familiarity marked by only $28.9 \%$. There is no big difference in familiarity of the crime identity theft. A percent of $50.4 \%$ familiar to this and $49.6 \%$ are unfamiliar to this crime. A simple majority (54.1\%) know the term cyber pornography. The remaining $45.9 \%$ is totally unfamiliar to this crime.

Table 9: Familiarity with crime against property

\begin{tabular}{|l|l|l|}
\hline Cyber-crimes & Familiar & Not familiar \\
\hline Hacking & $122(90.4 \%)$ & $13(9.6 \%)$ \\
\hline Dictionary program & $49(36.3 \%)$ & $86(63.7 \%)$ \\
\hline Malware & $64(47.4 \%)$ & $71(52.6 \%)$ \\
\hline Sniffing & $26(19.3 \%)$ & $109(80.7 \%)$ \\
\hline Software piracy & $75(55.6 \%)$ & $60(44.4 \%)$ \\
\hline Corporate Espionage & $9(6.7 \%)$ & $126(93.3 \%)$ \\
\hline
\end{tabular}

(Note: Figures in parentheses denote percentage)

Familiarity table of cyber-crime against property shows that a vast majority of sample (90.4\%) are familiar to hacking. Only a least minority $(9.6 \%)$ is unfamiliar with this term. But dictionary program is unfamiliar to a $63.7 \%$ of sample population. Only a large minority (36.3\%) are familiar with the term. A vast majority (47.4\%) are familiar with the term malware programs. And the remaining samples (52.6\%) are totally unfamiliar with malwares. The term sniffing is strange for a large majority $(80.7 \%)$. Only a small minority knows the term sniffing. Majority of sample population (55.6\%) recognized the term software piracy. A vast minority (44.4\%) don't recognize the term. In the case of corporate espionage, a vast majority of 93.3 percent is totally unfamiliar with this term. Its known percent accounts only 6.7 percent.

Table 10: Familiarity with crime against Society

\begin{tabular}{|l|l|l|}
\hline Cyber-crimes & Familiar & Not familiar \\
\hline Cyber terrorism & $91(67.4 \%)$ & $44(32.6 \%)$ \\
\hline Web jacking & $65(48.1 \%)$ & $70(51.9 \%)$ \\
\hline
\end{tabular}

While considering the case of crime against society, samples response show that a large majority (67.4\%) familiar with the term cyber terrorism. Only a large minority (32.6\%) are unfamiliar to cyber terrorism. In the case of web jacking, a vast minority (48.1\%) knows the term. And a simple majority (51.9\%) is totally unfamiliar with the term.

\section{VI.4 Awareness on computer security measures}

Table 11: Computer security measures

\begin{tabular}{|c|c|c|c|}
\hline Security & es $\quad \mathbf{Y}$ & & No \\
\hline Up to date with computer security & $\begin{array}{r}8 \\
4(62.2 \%)\end{array}$ & $7.8 \%)$ & $51(3$ \\
\hline Password for computer & $7(71.9 \%)^{9}$ & $8.1 \%)$ & $38(2$ \\
\hline $\begin{array}{l}\text { Allow others to use your face book, email } \\
\text { accounts }\end{array}$ & $0(14.8 \%)^{2}$ & $85.2 \%)$ & 115( \\
\hline Revealed passwords of accounts with others & $\begin{array}{r}1 \\
8(13.3 \%) \\
\end{array}$ & $86.7 \%)$ & 117( \\
\hline Safety tips in cyber space & $3(54.1 \%)^{7}$ & $5.9 \%)$ & $62(4$ \\
\hline $\begin{array}{l}\text { Sharing personal information with unknown } \\
\text { persons in cyber space }\end{array}$ & $6(19.3 \%)^{2}$ & $80.7 \%)$ & 109( \\
\hline
\end{tabular}

A majority of sample keeps up to date with computer security. They keep passwords and follow safety tips in cyber world. A large majority of sample (62.2\%) keep up to date with computer security. A large 
majority of sample (71.9\%) keep a password for their computer. And a large minority (28.1\%) doesn't have it. A simple minority of sample (14.8\%) allow others to use their various social media accounts. A simple minority of sample (13.3\%) revealed their passwords with others. But a large majority $(86.7 \%)$ doesn't reveal their passwords with others. People who keep safety measures account a large majority (54.1\%) of sample population. A large majority of sample $(80.7 \%)$ never shared any personal information with unknown persons. But a simple minority $(19.3 \%)$ does this while chatting.

\section{DISCUSSION}

Information Technology Act was introduced in 2000 in order to deal with mischievous activities happening in the cyber world. Being the regular users of internet and related technologies, most of them are aware of legal precautions in the cyber world. Even though most of them have a basic level of understanding about act applied in cyberspace, their level of understanding is different. Nowadays, IT Act is part of academic curriculum. So, most of the youth are getting basic awareness about IT Act from classrooms itself. Interestingly, self-learning happens with the rarest.

Youth of Malappuram is familiar with Information Technology Act 2000, even though most of them never gone through this act once in life. Among the familiar ones a large minority never read this act properly. It may be because of lack of interest to read or unavailability of the full text of the act. Another reason was most of them never faced a crucial situation to deal with the cyber law.

All human beings have the basic common sense to identify a crime. Every individual in this world know that killing is a punishable crime. But their readability of constitution and other legal texts may be less. They recognise a crime with their intelligence and life experiences. This is same for cyber offences also. The youth of Malappuram identifies various offences in IT Act, 2000. Youth's awareness on different offences (sections) in IT Act is varying. They have a clear cut idea about offences stated in some sections of IT Act. But certain sections are confusing and they are ignorant about offences contained in them. The basic commonsense and intelligence to recognise an offence lead to high awareness on some sections of the act.

Intentionally do something to harm others mentally or physically is a crime. Even if it is a computer source code, it's an offence. The youth of Malappuram are well aware of this offence in IT Act. Their life experience and knowledge taught them it as a crime. This is same for many sections in IT Act. Life experience and wisdom make youth aware about offences in cyberspace. The aware offences are known to youth from news reports, films and many other sources in the day to day life.

Interestingly, youth has a very limited level of understanding with some sections.They are not aware of someoffences such as receivinga stolen computer resource, failure to maintain records on time, refusing orders of the controller and committing a crime outside India. These offences are new to them and not familiar with as these are happening in an organisational setup more often.

The familiarity of IT Act and awareness on some sections has a significant connection. Youth who know act identifies offences in various sections. As usual non-familiarity of the act and lack of awareness on offence is directly related to each other.

Gender, education, age and area of living are the important factors in human life. All these things play a crucial role in understanding something new in life. In the case of Information Technology act age is an important factor in understanding the cyber law. Gender, education and area of living don't have any significance in understanding the cyber law in India. Youth become less unfamiliar about act while age group increases. Malappuram youth were literates. But formal education is not a important factor in understanding IT Act. There is no big difference in the familiarity of the act among youth who lives in rural and urban areas of Malappuram. Both male and female are aware of IT Act. It indicates that area of living and education are not a matter to understand cyber laws in India.

Malappuram youth have a basic understanding of various cybercrime terms. But their familiarity is limited. The most happening crimes were familiar to them. Crimes like cyber stalking, social engineering, sniffing, dictionary program and corporate espionage are the most unfamiliar terms for Malappuram youth. Hacking and cyber terrorism are somewhat familiar to youth.

The youth of Malappuram is staying away from doing mischievous activities in cyberspace. Most of the youth never committed cyber crimes once in life. But there are exceptional cases. All sorts of crimes is committed to a mild level. Bulk mailing, cyber stalking and social engineering committed in moderate level. Lack of awareness about punishments, psychological problems of individual may be the reasons for committing crimes to a moderate level. Also, some people will have a tendency to harm others mentally or physically.

\section{CONCLUSION}

Most of the youth are familiar with IT Act, 2000 in India. But some are ignorant about it. It's necessary to make them aware of this legal system because we are living in a highly sophisticated e- world. Here chances 
for getting trapped are very high. So it would be better if the cyber authorities conduct law awareness programs for users of cyberspace.

Basic ethics and IT applications usage etiquettes should be introduced into the regular course curriculum during schooling. Authorities should give special attention to reduce the fear of public to approach legal authorities. One can take help of media especially social media to transmit messages about IT security and related issues. The present study arrives at the fact that youth of Malappuram are familiar with Information technology Act, 2000. Most of the offences in act are familiar to them. But a few of them are totally ignorant about this act. Youth have an idea about security measures in computer too.

\section{REFERENCES}

[1] E.Balagurusamy. (2008). Computing Fundamentals and C Programming. New Delhi: Tata McGraw-Hill Publishing Company Limited.

[2] Jones, S. (1995). Cyber Society: Computer Mediated Communication and Community. California: SAGE publication.

[3] Krishna Kumar, S.R.Sharma. (2002). Cyber Laws Intellectual Property and E-Commerce Security. New Delhi: Dominant Publishers and Distributors.

[4] Lim, Y. F. (2002). Cyberspace Law: Commentaries and Materials. New York: Oxford University Press.

[5] Narayan, A. (2000). Internet Marketing E-Commerce and Cyber Laws. New Delhi: Authors Press.

[6] V.D.Dudeja. (2001). Information Technology and Cyber Laws. New Delhi: Ajay Verma for Commonwealth Publishers.

[7] Yar, M. (2006). Cybercrime and Society. London: SAGE Publications Ltd. 